\section{HUMAN MOVEMENT REPRESENTATION IN VIRTUAL ENVIRONMENT USING GAMING SOFTWARE}

Shahrol Mohamaddana*, Syed Tarmizi Syed Shazalia, Ana Sakura Zainal Abidina, Keith Caseb

aFaculty of Engineering, Universiti Malaysia Sarawak, 94300 Kota Samarahan, Sarawak, Malaysia

bMechanical and Manufacturing Engineering, Loughborough University, Leicestershire, LE 11 3TU, United Kingdom
Article history

Received

30 July 2015

Received in revised form

30 September 2015

Accepted

31 October 2015

*Corresponding author mshahrol@feng.unimas.my

\section{Graphical abstract}
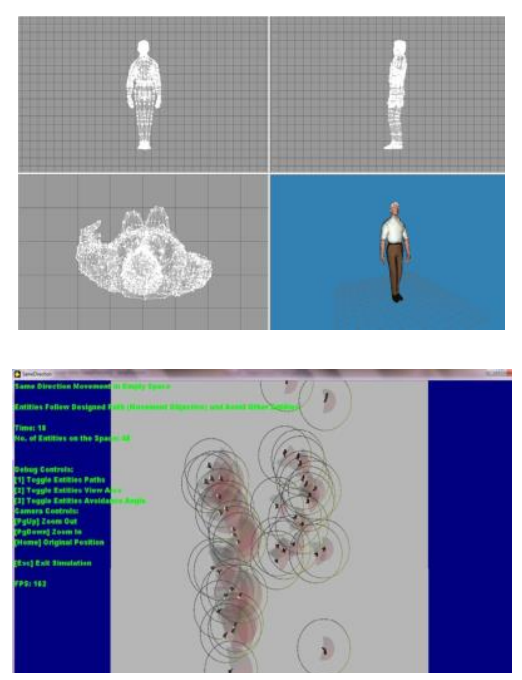

\begin{abstract}
Human movement in crowd can be considered as complex and unpredictable. In this research, image analysis, video observation and conceptual behaviour was developed as a method to understand the human movement in crowd. Based on the method, human movement was represented or converted into the virtual environment using gaming software called DarkBASIC Professional (DBPro). The developed program using DBPro was applied as a tool to simulate and predict human movement in different building layout. Two subjects (adult and older people) were selected as the virtual entities. Human movement at the bottleneck and non-bottleneck layout was presented in this paper as example of case study.
\end{abstract}

Keywords: Human movement; virtual; gaming software; darkbasic; simulation

\begin{abstract}
Abstrak
Pergerakan manusia di dalam keadaan yang sesak adalah kompleks dan sukar dijangka. Di dalam penyelidikan ini, analisa imej, pemerhatian video dan konsep tabiat manusia telah dibangunkan sebagai kaedah untuk memahami pergerakan manusia di dalam keadaan yang sesak. Berdasarkan kaedah tersebut, pergerakan manusia telah ditukar ke dalam persekitaran maya menggunakan perisian permainan yang dikenali sebagai DarkBASIC Professional (DBPro). Program yang telah dibangunkan menggunakan perisian tersebut telah digunakan sebagai alat untuk melakukan simulasi dan meramal pergerakan manusia di dalam susunatur bangunan yang berbeza. Dua subjek iaitu orang dewasa dan orang tua telah digunakan sebagai entiti maya. Pergerakan manusia di susunatur sempit dan kurang sempit telah digunakan sebagai contoh di dalam risalah ini.
\end{abstract}

Kata kunci: Pergerakan manusia; maya; perisian permainan, darkbasic; simulasi

(C) 2015 Penerbit UTM Press. All rights reserved

\subsection{INTRODUCTION}

A crowd can be defined as a large group of individuals in the same physical environment and sharing a common goal [1]. Crowds can occur in many places including for example train stations, shopping mall and stadium. Human movement in crowd can be considered as complex and unpredictable. In this research, emphasize is placed on gaining knowledge of some of the characteristics of human movement in the real world and model the humans in the virtual environment. 